\title{
The Preclusion Sanction-A Violation of the Constitutional Right to Present a Defense
}

In the recent case of Williams v. Florida, ${ }^{1}$ the Supreme Court apparently laid to $\mathrm{rest}^{2}$ the strongest possible challenge to the constitutionality of pretrial discovery by the prosecution, in finding that such discovery did not violate the defendant's Fifth Amendment privilege against self-incrimination. ${ }^{3}$ This decision would seem to confirm the validity of state pretrial notice statutes-requiring, for example, notice of an intention to raise the defense of alibi, ${ }^{4}$ insanity, ${ }^{6}$ or self-defense $e^{6}$-and expanded prosecutorial discovery under proposed rules $12.1,{ }^{7} 12.2^{8}$ and $16(b)^{9}$ of the federal rules of criminal procedure. However, the amicus brief submitted in Williams also challenged the constitutionality of the sanctions authorized by these statutes to en.

1. 399 U.S. 78 (1970). This case upheld the validity of a Florida notice of alibi statute, against the contention that, in requiring pretrial disclosure by the defendant, the statute violated the defendant's Fifth Amendment privilege against self-incrimination. In finding no such infringement the Court held that the pretrial disclosure was "not compelled self-incrimination transgressing the Fifth and Fourtenth Amendments." Id. at 85 .

2. But see Note, Prosecutorial Discovery Under Proposed Rule 16, 85 HAkv, L. RLv. 994, 1007-09 (1972), in which the holding of Williams is criticized and the opposite position is expounded, i.e., that forced pretrial disclosure by the defendant does violate his Fifth Amendment privilege against self-incrimination.

3. 399 U.S. at 86 .

4. Sixteen states have notice of alibi statutes. See, e.g., FlA. R. CRIM. P. 1.200 (1967); Kan. Stat. ANN. \$ 22-3218 (Supp. 1971); OKLa. Srat. ANN. tit. 22, \$ 585 (1969).

5. Fourteen states have some notice of insanity or special plending statute. Sce, e.g., Arizona R. Crim. P. 192(A) (1956); Kan. Stat. ANN. \$ 22-3219 (Supp. 1971); Micil. Couir. LAWS ANN. $\$ \S 768.20,768.21$ (1968).

6. See, e.g., MoNr. REv. CodEs ANN. $\$ 95-1803$ (d) (1967).

7. Proposed Rule 12.1, in relevant part, is a notice of alibi procedure under which pretrial notice of alibi witnesses must be submitted by the defendant. If notice is not given, the defendant may, in the discretion of the court, be precluded from offering those witnesses at trial. However, no limitation is placed on the right of the defendant to testify in his own behalf. Preliminary Draft of Proposed Amendments to the Federal Rules of Criminal Procedure for the United States District Courts, 52 F.R.D. 409, 432.39 (1971) [hereinafter cited as Proposed Rule 12].

8. Proposed Rule 12.2 is a notice of insanity procedure in which the defendant must serve notice of his intention to rely on the defense of insanity or his intention to call expert witnesses concerning the issue of requisite mental state, prior to trial. In contrast to rule 12.1, this rule is silent as to use of the preclusion sanction. Id. at 435.36 .

9. Proposed Rule 16(b) would require that, upon motion of the government, the defendant disclose all documents and tangible objects, reports of examinations and tests, and the names of all witnesses that the defendant intends to use at trial. In the cvent that the defendant fails to disclose such information, the court pursuant to $16(d)(8)$ may, in its discretion, preclude the defendant from offering that evidence at trial. Prc. liminary Draft of Proposed Amendments to the Federal Rules of Criminal Procedurc for the United States District Courts, 48 F.R.D. 553, 591, 593.94 (1970) [hereinafter citcd as Proposed Rule 16]. The proposed rule permits much broader prosccutorial discovery than the existing rule, 16 (c): first, by not making the government's discovery conditional on a prior motion for discovery by the defendant; and second, by broadening the scope of mandatory discovery to include reports of examinations and tests and a list of pro. posed witnesses. Compare FED. R. CRIM. P. 16(c). 
force the discovery orders. ${ }^{10}$ Most of the statutes, including the Florida statute $^{11}$ involved in Williams and both the current ${ }^{12}$ and proposed ${ }^{13}$ federal rules on discovery, provide that in the event notice is not given or evidence disclosed, the judge, in his discretion, may preclude the defendant from offering that evidence at trial. ${ }^{14}$ Moreover, such preclusion is permissible irrespective of the materiality of the proffered evidence $^{15}$ or the manner of its presentation (e.g., through testimony by the defendant, ${ }^{16}$ testimony by other witnesses, ${ }^{17}$ or through tangi$\mathrm{ble}^{18}$ or documentary ${ }^{19}$ evidence). While the Court in Williams found it unnecessary to assess the constitutionality of this sanction, ${ }^{20}$ since the defendant had complied with the statute initially, use of preclusion in this context raises serious constitutional questions. ${ }^{21}$ This Note will examine the degree to which the preclusion sanction infringes upon the constitutional rights of the accused and evaluate the possible justifications for this infringement in light of the state interest in pretrial discovery.

\section{The Right to Present a Defense}

\section{A. Preclusion-An Evidentiary Basis}

In order to assess the constitutionality of the preclusion sanction, it is first necessary to indicate the principal theories which have been offered to justify imposition of the sanction. The first of these might

10. Brief for Virgil Jenkins as Amicus Curiae at 17-26, Williams v. Florida, 399 U.S. 78 (1970).

11. Fla. R. CRMr. P. 1.200 (1967).

12. FED. R. CRIM. P. 16(g).

13. See Proposed Rule I2, supra note 7, at 432; Proposed Rule 16, supra note 9, at 593.94 .

14. There are two exceptions to the general rule stated in the text. In hansas, the notice of alibi statute provides for mandatony preclusion while in Oklahoma, only a continuance can be granted to the prosecution if the defense fails to give the required notice. KaN. Stat. ANN. \$ 22-3218(4) (Supp. 1971); OKLA. STAT. .1NN. tit. 22, \$ 285 (1969).

15. State v. Thayer, 124 Ohio St. 1, 4, 176 N.E. 656, 657 (1931).

16. See State ex rel. Simos v. Burle, 41 Wis.2d 129, 133-34, 163 X.W.2d 177, 178-79

(1968) interpreting the Wisconsin notice of alibi statutc, Wtsc. Srat. Axs. \$ 955.07 (1967), reinacted as WISC. STAT. ANN. $\$ 971.23$ (1969), to authorize the preclusion of the defendant from testifying about an alibi where he failed to give notice. Bul sec, has: STAT. ANN. \$22-3218(4) (Supp. 1971), in which testimony by the defendant is specifically excepted from the operation of the preclusion sanction.

17. E.g., Proposed Rule 12, supra note 7, at 432.

18. E.g., Fed. R. Casir. P. 16(c) \& 16(g).

19. Id.

20. Williams v. Florida, 399 U.S. 78, 83, n.14 (1970). See also Radford v. Stewart, 320 F. Supp. 826, 830 (D. Mont. 1970), in which the question of the constitutionality of preclusion was noted but, again, because the sanction was not actually applied, the question was left unanswered.

21. See Proposed Rule 12 (Advisory Committec Notes), supra note 7, at 434-35. 
be termed the punitive justification and is based on the belief that preclusion is the only effective means by which the state can enforce its pretrial discovery statutes. ${ }^{22}$ The validity of this justification in light of the possible constitutional infirmities of the sanction, will be considered in Part II of this Note. ${ }^{23}$ The second rationale might be termed the evidentiary basis for preclusion. It is based on a belief that preclusion, as it is traditionally practiced, is used only to render incompetent ${ }^{24}$ evidence inadmissible, a procedure which has never been thought to infringe upon the rights of a defendant at trial.

This latter theory finds support, at least in civil cases, ${ }^{25}$ in the reasoning of the Supreme Court in Hammond Packing Co. v. Arkansas. $^{26}$ In that case, the Court was called upon to determine the constitutionality of an Arkansas civil pretrial discovery statute under which the preclusion sanction had been imposed upon the defendant for his wilful refusal to comply with an order requiring production of witnesses, books and documents. In rejecting the contention that the sanction violated due process, the Court said:

This case presents a failure by the defendant to produce what we must assume was material evidence in its possession and a resulting striking out of an answer and a default. The proceeding here taken may therefore find its sanction in the undoubted right of the lawmaking power to create a presumption of fact as to the bad faith and untruth of an answer begotten from the suppression

22. Id. at 435; Kaufman, Discovery in Criminal Cases, 44 F.R.D. 481, 488 (1967).

23. See pp. 1353-61 infra.

24. Though the text analyzes the primary evidentiary basis for the sanction, a slightity different rationale is offered by courts in states in which the notice of insanity pro. cedure, for instance, is incorporated into the pleading requirements. E.g., CAL. PENAL CODE $\$ 1016$ (West 1972); WASH. REv. CODE $\$ 10.76 .020$ (1961). In those states, fallure to plead the insanity defense is viewed as precluding the future offer of that defense at trial. Consequently, when the defendant attempts, at trial, to offer cvidence concerning insanity, the court will rule that such evidence is immaterial rather than incompetent, on the premise that the defense of insanity is not at issuc. State v. Bonutr, 53 Wash.2d 575, 587, 335 P.2d 462, 469 (1959); State v. McLain, 199 Wash. 661, 665, 92 P.2d 875, 877 (1939). Yet, this approach does not remedy the constitutional defect of preventing the defendant from presenting a defense which, if established despite the procedural omission, would render him free of criminal liability under the substantive law of the jurisdiction. See discussion in text under the Sixth Amendment Right to Compulsory Process, pp. 1345-51 infra.

However, it should be noted that the above analysis would not apply to a split trial procedure, such as that in California. As the California Supreme Court observed in People v. Wells, 33 Cal.2d 330, 355, 202 P.2d 53, 68 (1949), in response to a due process attack on the split trial procedure, the split trial only alters the timing of the presentation of evidence concerning the insanity defense, it does not preclude that defense from being offered.

25. The Supreme Court has never adjudicated the constitutionality of the preclusion sanction in a criminal case.

26. 212 U.S. 322 (1909). Despite its agc, this case is still regarded as support for the preclusion sanction embodied in Rule 37 of the Federal Rules of Civil Procedure. Sec Advisory Committee and Historical Notes, 28 U.S.C.A. Rule 37 (1968). 
or failure to produce the proof offered, when such proof concerned the rightful decision of the cause .... In this the preservation of due process was secured by the presumption that the refusal to produce evidence material to the administration of due process was but an admission of the want of merit in the asserted defense.2:

Similarly, the Wisconsin Supreme Court, in a recent criminal case, sustained the preclusion of a defendant from testifying in his own behalf because of a failure to comply with an alibi notice statute, on the grounds that:

What is constitutionally protected is the right of a defendant to testify truthfully in his own behalf . . . . These decisions [prior holdings by the Wisconsin Supreme Court upholding the preclusion sanction] and the statute on which they are based, do not limit in any way the right of a defendant to testify trulkfully in his own behalf. The condition of prior notice as to alibi testimony, like the test as to materiality and relevancy, does not invade the right of a defendant to testify in his own defense.28

In short, both of these courts seem to find no conflict between due process and the preclusion of otherwise relevant and material evidence on the theory that the failure to comply with pretrial discovery makes such evidence presumptively unworthy of belief and the resulting incompetency of the evidence justifies its inadmissibility. However, in the case of Washington $v$. Texas, ${ }^{29}$ the Supreme Court shattered the constitutional underpinning of this theory when it expressly held that the establishment of such a priori categories of incompetency, based on presumed untrustworthiness, violates the defendant's Sixth Amendment right to compulsory process-his right to present a defense..$^{30}$

\section{B. The Sixth Amendment Right to Compulsory Process ${ }^{31}$}

\section{The Washington Case}

In 1964 a group of youths, including Jackie Washington and Charles Fuller, drove to the home of Washington's ex-girlfriend and began

27. 212 U.S. at $350-51$ (emphasis added).

28. State ex rel. Simos v. Burke, 41 Wis.2d 129, 137-38, 163 N.W.2d 177, 181 (1968) (emphasis added).

29. 388 U.S. 14 (1967).

30. Id. at 22.

31. The Sixth Amendment of the Constitution provides, in pertinent part: "In all criminal prosecutions, the accused shall enjoy the right to ... have compulsory process for obtaining witnesses in his favor .... U.S. CoNst., amend. VI. 
hurling bricks at the house. After the rest of the group returned to the car, Washington and Fuller were left alone outside the house with a loaded shotgun that Fuller had brought. When the girl's new boyfriend emerged to investigate the disturbance, either Washington or Fuller fired the shotgun and killed him. On trial for murder in a state court in Texas, Washington desired to have Fuller testify to the effect that Washington had unsuccessfully tried to persuade Fuller not to shoot and, in fact, had run back to the car before Fuller had shot the boy. As Fuller had been convicted of murder in a prior trial, it was undisputed that he would have testified and that his "testimony would have been relevant and material, and that it was vital to the defense." 32 In spite of this, the trial court, on motion of the State, refused to allow Fuller to testify because of a Texas statute which prohibited co-principals from testifying in each other's behalf. Eight members $^{33}$ of the Supreme Court agreed in holding that:

[ the petitioner in this case was denied his right to have compulsory

- process for obtaining witnesses in his favor because the State arbitrarily denied him the right to put on the stand a witness who was physically and mentally capable of testifying to events that he had personally observed, and whose testimony would have been relevant and material to the defense. ${ }^{34}$

In reaching this conclusion, the Court first established that the right to present a defense, traditionally held to be a fundamental element of due process of law, ${ }^{35}$ was in fact the embodiment of the Sixth Amendment right to compulsory process.

The right to offer the testimony of witnesses, and to compel their attendance, if necessary, is in plain terms the right to present a defense, the right to present the defendant's version of the facts as well as the prosecution's to the jury'so it may decide where the truth lies. Just as an accused has the right to confront the prosecution's witnesses for the purpose of challenging their testimony, he has the right to present his own witnesses to establish a defense. This right is a fundamental element of due process of law..$^{36}$

32. 388 U.S. at 16 .

33. The ninth, Justice Harlan, concurred in the holding on the grounds that, since the Texas statute in question was irrational, it violated the duc process clatise of the Fourteenth Amendment. However, he disagreed with the majority's interpretation of the Sixth Amendment Compulsory Process Clause to include the right to present as well as obtain witnesses. In addition, he repeated his criticisin of the selective incor. poration doctrine, which, in this case, the majority had applied to Sixth Amendment Compulsory Process in order to make it binding upon the states. 388 U.S. at 23.25 (Harlan, J., concurring).

34. Id. at 23 .

35. Specht v. Patterson, 386 U.S. 605, 610 (1967); in re Oliver, 333 U.S. 257, 273 (19.18).

36. 388 U.S. at 19. 
In thus going beyond a literal reading of the Sixth Amendment, which speaks only of "obtaining" witnesses, the Court considered the historical purpose of that portion of the Amendment-to overcome the common law disqualification of all defense witnesses ${ }^{37}$ -and concluded that the right to obtain witnesses must naturally import the right to examine them. ${ }^{38}$ In short, the Court found that "[t]he Framers of the Constitution did not intend to commit the futile act of giving to a defendant the right to secure the attendance of witnesses whose testimony he had no right to use."39

Having established that a defendant has a right to examine all witnesses, the Court then sought to give that right some meaning against common law or statutory disqualification. At the outset, it is clear from the holding that the Court was not contesting the validity of the broad evidentiary requirements which, to be sure, limit the admissibility of testimony: specifically, that testimony must be relevant and material, ${ }^{40}$ be the result of personal observation, ${ }^{41}$ and be given by a witness who is physically and mentally capable of perceiving and relating events to the court. ${ }^{42}$ However, the statute in Washington

37. 2 J. StoRY, Constrmution of THE UNrTEd States \$ 1 792 (4th cd. 1873).

38. Accord United States v. Burr, 25 F. Cas. 30, 32 (No. 14, 692d) (C.C.D. Va. 1807); State ex rel. Brown v. Dewell, 167 So. 687, 690 (Fla. 1936).

39. 388 U.S. at 23.

40. Hardin v. State, 471 S.W. $2 d$ 60, 62 (Tex. App. 1971); State v. Groppi, 41 Wis.2d $312,323,164$ N.W.2d 266, 271 (Wis. 1969), rev'd on other grounds, 100 US. 505 (1971). Thus, there may be no violation of equal protection where indigents are required to make a showing of materiality under FED. R. CRIM. P. 17(b), in order to obtain witnesses at government expense. Hoskins v. Wainwright, 440 F.2d 69, 71 (5th Cir. 1971); Slawck: v. United States, 413 F.2d 957, 959-60 (8th Cir. 1969). However, sec Unitcd States v. Seeger, 180 F. Supp. 476,468 (S.D.N.Y. 1960) in which it was licld that the very requirement of a prior showing of materiality, where no question of government expenditure is involved, violates the right to compulsory process.

41. This comports with the traditional evidentiary rule that hearsay testimony is inadmissible. See 5 J. Wigmore, Evidence $\$ 1361$, 1362 (3d cd. 1940). Nerertheless, it should be noted that the hearsay exclusion may deprive a defendant of relevant cridence, on the grounds that such evidence is presumptively unwortly of belief. Id. $\$ 1362$. In fact, it has been suggested that this result may be constitutionally suspect, as a violation of due process. Weinstein, Alternatives to the Present Hearsay Rulcs, 44 F.R.D. 375, 380-86 (1968). However, there are important differences between the use of an irrebuttable presumption of untrustworthiness in the hearsay context, and similar use in the context of testimonial incompetence, based on the likelihood of perjury. In the latter instance, it has been argued that the effectiveness of both cross-exanination and perjury sanctions, in reducing the probability of false testimony, renders the broad sweep of preclusion unnecessary. See note 53 infra. On the other hand, neither of these safeguards, cross-examination or the perjury sanction, an be applied to mitigate the possibility of false testimony by an extra-judicial declarant. 5 J. Wicsone, Evidesice \$ 1361 (3d ed. 1940). Consequently, while an exclusionary rule, as applied to hearsay, may be sustainable as the only means of preventing this source of false testimony, a similar argument cannot be made to justify the exclusion of in-court testimony as in. competent because of the likelihood of its falsification. Compare note 60 in/ra.

42. However, even as to these more readily discernible grounds of incompctency, a broad, a priori rule of exclusion has been criticized. See $2 \mathrm{~J}$. W'icmore, Evidesce \$S 492. 500,501 (3d ed. 1940). Consequently, as a general matter, courts will disqualify proposed witnesses only after an individual examination confirms their disability. 
involved another aspect of witness capacity: veracity. This was the category of incompetency-including disqualification based on interest, ${ }^{43}$ moral capacity ${ }^{44}$ or other factors which might affect the truthfulness of the testimony-that the Court found to be in conflict with the Sixth Amendment right to compulsory process. In the words of the Court,

It is difficult to see how the Constitution is any less violated [in comparison with the exclusion of all defense testimony] by arbitrary rules that prevent whole categories of defense witnesses from testifying on the basis of a priori categories that presume them unworthy of belief. 45

In support of this position, the Court stressed the aforementioned purpose of the compulsory process clause-to overcome the common law disqualification of all defense witnesses-and the consistent judicial and legislative trend toward elimination of the various disqualifications based on presumptive untrustworthiness. ${ }^{46}$ Specifically, the Court stated that its reasoning in Rosen $v$. United States, ${ }^{47}$ in which the Court had struck down a common law rule of disqualification based on moral incapacity, was required by the Sixth Amendment.48 Consequently, although the statute in Washington was based on a form of interest incompetency, ${ }^{40}$ it seems evident that the holding cannot be limited to the particular source of presumptive untrustworthiness considered in that case.

Although a broad reading of the Sixth Amendment to include a constitutional definition of competency has been criticized, ${ }^{50}$ such an

43. Id. $\$ 575$.

44. Id. \$ 515 .

45. Washington v. Texas, 388 U.S. 14, 22 (1967).

46. The Court cited Rosen v. United States, 245 U.S. 467 (1918) (id. at 22) and Ferguson v. Georgia, 365 U.S. 570 (1961) (id. at 20) in which both of these trencls are discussed.

47. 245 U.S. 467 (1918). In Rosen, the issue of a witness' competency to testify, despite a prior crime conviction, was before the Court. Whereas prior cases had held that the state law at the time of the Judiciary Act of 1789 was controlling. Unitcd States $v$. Reid, 53 U.S. (12 How.) 361 (1851), and pursuant to that law, the witness in question was properly ruled incompetent, the Court found "that the dead hand of the common. law rule of 1789 should no longer be applied . . . Rosen v. United States, 245 U.S. 467,471 (1918). In so holding, the Court took note of the judicial and legislative trend toward removing such restrictions, $i d$, and the policy consideration that:

the truth is more likely to be arrived at by hearing the testimony of all persons of competent understanding who may seem to have knowledge of the facts involved in a case, leaving the credit and weight of such testimony to be determined by the Id.

jury or by the court, rather than by rejecting witnesses as incompetent ....

48. 388 U.S. at 22.

49. Id. at $20,21$.

50. See Note, Right of Defendant to Have Testimony of Co.Participant, 20 BuYLok L. REv. 467, 472 (1968); Note, The Sixth Amendment Guarantee of Compulsory Process is Violated, 46 TeXas L. REv. 795, 797 (1968). 
interpretation seems consistent with the basic purpose of the right to compulsory process. Simply stated, that purpose is to assure a vigorous adversary proceeding by affording the defendant the means of presenting witnesses in his favor to at least the same degree that the government can use witnesses against him. ${ }^{52}$ The fundamental goal of the trial process-the search for truth ${ }^{52}$-thereby will be served. Moreover, considering that goal, the leading commentators ${ }^{33}$ agree that the risk of false testimony does not justify the cost of keeping otherwise relevant evidence from the jury, given the difficulty of determining a priori whether an individual is likely to speak the truth, the opportunity to attack witness credibility on cross-examination, and the availability of sanctions against perjury. As Professor Morgan succinctly put it, "[N]o rational procedure will sanction an exclusionary rule supported only by its supposed efficacy to hinder or prevent false testimony." 34

Finally, although the Court in Washington found the Texas statute irrational because it did not even set apart a group of persons particularly likely to commit perjuryss such a finding of irrationality was probably not essential to the outcome of the case. The question before the Court was whether a legislature had the power to establish a presumption of untrustworthiness, the effect of which was to render inadmissible otherwise relevant and material evidence. An adequate evaluation of the rationality of such a presumption requires more than the establishment of a rational connection between the proven fact ${ }^{56}$ and the presumed fact. ${ }^{57}$ In addition, the burden of proof required of the defendant to overcome this presumption must also be assessed.58 The greater this burden the less likely it will be that defendants offering truthful testimony will be able to overcome the presumption, and therefore the stronger the likelihood of perjury must be. ${ }^{59}$ In the case of irrebuttable presumptions like the one in Washington, the burden can never be met. Therefore, whenever the Court is faced with an irrebuttable presumption of untrustworthiness,

51. In re Dillon, 7 Fed. Cas. 710, 712 (No. 3914) (N.D. Calif. 1854).

52. Tehan v. United States ex rel. Shott, 382 U.S. 406, 416 (1960).

53. See, e.g., 2 J. Wigmore, Evidexce $\$ S 515,576$ (3d ed. 1910). See also C. IrcCoririch,

LAW OF EVIDENCE $\$ 71$ (1954).

54. Morgan, Foreword to ALI Model Code of Evidevce, at 6 (1912).

55. Washington v. Texas, 388 U.S. 14, 22 (1967).

56. In Washington, for instance, the "proven fact" would be that the proposed witness,

Fuller, was a co-principal of the defendant.

57. The "presumed fact" would, of course, be that the proposed witness will be untrustworthy-will not testify truthfully.

58. Ashford \& Risinger, Presumptions, Assumplions and Due Process in Criminal

Cases: A Theoretical Overview, 79 Yale L.J. 165, 184.85 (1969).

59. Id. at 186 . 
it should require not merely a rational connection but virtually $\mathfrak{a}$ perfect correlation between the class of evidence designated and the assumption that such evidence would be false or misleading.00

The presumption of untrustworthiness upon which the preclusion sanction rests certainly does not reflect a strong enough correlation to satisfy the test described above. An assessment of the connection between the defendant's failure to disclose evidence and the truth or falsity of that evidence should focus on those factors which would lead the defendant to refuse to disclose truthful evidence. As an alibi defense may be the most easily fabricated, ${ }^{01}$ the rationality of preclusion as incorporated in the notice of alibi statutes should be examined closely.

There are three considerations which might motivate a defendant to withhold disclosure of true alibi witnesses. First, the defendant might seek the advantages of surprise which silence affords. Second, the defendant might fear intimidation or manipulation of his witnesses by the government, either through threats of prosecution or by offers of immunity or attractive bargains. Third, the defendant might wish to protect either the privacy of his witnesses or his relitionship with them from the intensive government investigation which would probably follow disclosure. ${ }^{22}$ Moreover, there is also the independent likelihood that the undisclosed witnesses will agree to commit perjury. The reasoning of Washington that inferences of perjury, based on a witness' interest or moral incapacity have insufficient rationality to support an irrebuttable presumption of untrustworthiness, surely destroys any argument that a witness' degree of friendship with the defendant will yet support that presumption. Consequently,

60. It may be argued that a presumption which fails to attain the proper degrec of correlation-like a presumption for which there is no rational conncction-is unconst 1 . tutional per se. But it would probably be more reasonable to allow the government to argue that the presumption under attack is sufficiently important to the effectuation of its valid interests as to overcome this requirement of a high degree of correlation. Sce discussion of the hearsay rule in note 41 supra. Such an argument would probably lead to a balancing procedure similar to the one described in Part II, pp. 1353.54 infru, itt which, assuming the state's interest in preventing false testimony to be compelling, the marginal increase in effectiveness of preclusion in satisfying that interest must be weighed against the danger that true testimony may be precluded. Yet, upon recexulu. ining the Court's reasoning in Rosen v. United States, 245 U.S. 467 (1918) (sec note 47 supra), reaffirmed by the Court in Washington, 388 U.S. at 22 , it scems clear that, consistent with the position of the leading commentators (see p. 1349 supra), this bitl. ance has already been resolved against preclusion.

61. See Note, supra note 2 , at 1010.

62. Everett, Discovery in Criminal Cases-In Search of a Standard, 1964 DUkE L.J. 477,498 (1964). While the discussion in the text focuses on the notice of alibi statutes, it should be added that where notice of insanity is at issue, the defendant may also desire to avoid the opprobrium and possible civil commitment which might accompany such revelation. 
although there may be a rational connection between intentional ${ }^{03}$ nondisclosure and falsity, the correlation hardly approaches a degree of predictability sufficient to justify the imposition of an irrebuttable presumption that prevents a defendant from introducing material evidence in his defense. In short, preclusion is merely another a priori classification of presumptive untrustworthiness which would seem to violate the defendant's right to present a defense. ${ }^{\text {s }}$

\section{Scope of that Right}

The Sixth Amendment right to compulsory process, the core of the right to present a defense, clearly establishes the defendant's right to present testimony in his own behalf. However, as preclusion may also apply to documentary and tangible evidence, ${ }^{65}$ the extent to which the right to present a defense covers these sources of evidence must be determined as well.

Both courts $^{66}$ and commentators ${ }^{67}$ have supported the proposition that the right to compulsory process must not be so narrowly con-

63. Where, however, the defendant's failure to disclose is unintentional-that is, in a case in which there is no wilful refusal to disclose known information-it is doubtful that there would be any rational connection between such nondisclosure and the truth or falsity of that evidence. See Societe Internationale v. Rogers, 357 U.S. 197, 212 (1958). This may explain why all pretrial discovery statutes, except for that of Kansas, provide the judge with discretion to deny preclusion for good cause shown. See note lit supra.

64. A similar conclusion of constitutional infirmity was reached by three members of the Supreme Court in a dissenting opinion to a denial of certiorari in the case of Braswell v. Florida, 400 U.S. 873 (1970). Brasu'ell involved a trial court's preclusion of a defendant's sole corroborating witness on the grounds that the witness had remained in the courtroom despite the prior announcement of a sequestration order. In his dissent, Justice Black, joined by Justices Douglas and Brennan, said,

I would grant certiorari in this case to hold that Florida cannot enforce a mere procedural rule by denying a criminal defendant his constitutional right to present witness on his own behalf .... While the "Witness Rule" has a valid purpose and can contribute to the search for truth, a breach of the rule cannot be used to deny a criminal defendant his constitutional right to obtain and present witnesses in his favor. U.S. Const., Amdt. VI; cf. Washington v. Texas, 388 U.S. 14 (1967).

$I d$. Nevertheless, it should be noted that both the defendant and his counsel in Brasuell were found to be innocent of any knowledge of their withess violation. Since the general rule in federal courts has been that preclusion is improper where the defendant and counsel are unaware of the violation, United States v. Schaefer, 299 F.2d 625, 631 (ith Cir. 1962), it may be that the dissent in Brasuell represents no real departure from precedent, except in its application of the federal rule to state courts. Mloreover, since most discovery statutes provide that preclusion can be avoided for good cause shown, see note 14 supra, the position of the dissenters in Brastell does not answer the more important question of whether preclusion is constitutional when the defendant infentionally refuses to comply with pretrial discovery.

65. See, e.g., Fed. R. CRMr. P. 16(c), 16(g); Proposed Rule 16, supra note 9, at 591 , 593-94.

66. Palermo v. United States, 360 U.S. 343, 362 (1959) (Brennan, J., concurring); United States v. Schneiderman, 106 F. Supp. 731, 735 (S.D. Calif. 1952).

67. 8 J. Wigmore, Evidence $\$ \$ 2191,2193,2200$ (3d cd. 1940); 3 F. Wihation, Cinisis.al. EvIDENCE $\$ \$ 1105,1106$ (11th ed. 1935). See also Note, A Defendant's Right to Inspeet Pretrial Congressional Testimony of Government Witnesses, 80 YALE L.J. 1388, 1398.99 (1971). 
strued as to be limited to testimonial evidence alone. In United Stale's v. Burr, ${ }^{68}$ Chief Justice Marshall, while riding circuit, was called upon to interpret the scope of the compulsory process clause in determining the propriety of a subpoena duces tecum sought by Burr to compel disclosure of letters in the hands of President Jefferson. In the course of holding that the subpoena should issue, Marshall said,

This court would certainly be very unwilling to say that upon fair construction the constitutional and legal right to obtain its process, to compel the attendance of witnesses, does not extend to their bringing with them such papers as may be material in the defense. The literal distinction which exists between the cases is too much attenuated to be countenanced in the tribunils of a just and humane nation. ${ }^{69}$

Although there have been suggestions that such documentary evidence is itself more "testimonial" in nature than tangible evidence, ${ }^{\text {70 }}$ that distinction seems equally "attenuated."71 In this respect, the strong dictum of the Court in Washington bears repeating:

The right to offer the testimony of witnesses, and to compel their attendance, if necessary, is in plain terms the right to present a defense, the right to present the defendant's version of the facts as well as the prosecution's to the jury so it may decide where the truth lies. ${ }^{2}$

Moreover, to argue that "the defendant's version of the facts" may not include tangible evidence under certain circumstances is to ignore the realities of the trial process. In a case where items of physical cvidence, such as bloodstains, fingerprints, or the alleged murder weapon are critical to the determination of guilt or innocence, they are ats much a part of the defendant's version of the facts as witnesses are

68. 25 F. Cas. 30 (No. 14, 692d) (C.C.D. Va. 1807).

69. Id. at 35 .

70. Sec Note, supra note 67 , at 1399 .

71. Similarly, in a second area in which there has been reliance on the right to present a defense-namely, mandatory, prosecutorial disclosure pursuant to the Court's holding in Brady v. Maryland, 373 U.S. 83 (1963)-no such distinction betwecil docu. mentary and tangible evidence has been made. See Proposed Rule 16 (Advisory Conll. mittee Notes), supra note 9, at 602; Note, The Prosecutor's Constilutional Duty to Re't'al Evidence to the Defendant, 74 YALE L.J. 136, 147 (1964). In urging that Brady must be read as recognizing the defendant's right to present a defense, commentators have citcel due process and not compulsory process as the source of that right (Note, supra it $142-45$ ). It is clear, however, that the Court in Washington found the two synonymous in affording the defendant the right to present all material evidence in his belialf. 388 U.S. at 19 .

72. 388 U.S. at 19 . 
in other cases. Therefore, the relevance and materiality of the proffered evidence, rather than its form, must govern the applicability of the Sixth Amendment right to compulsory process.

\section{Justification Despite Infringement}

Constitutional rights are not absolute. Regardless of which doctrinal analysis is applied-compelling state interest, conditional privilege or waiver-courts have recognized that there can be justification for the resulting limitation of a constitutional right. Consequently, in assessing the constitutionality of the preclusion sanction, a finding of infringement of the Sixth Amendment right to present a defense is not enough. A further investigation into possible justifications must be conducted.

\section{A. Compelling State Interest Test}

Occasionally, courts have found justification for incidental infringement of even the most fundamental constitutional rights where that infringement was essential to the implementation of a compelling state interest. ${ }^{73}$ Pursuant to this theory, a determination of the constitutionality of an infringement of the defendant's Sixth Amendment rights rests on the following two-step analysis. First, the Court must assess the urgency of the state interest, for if that interest cannot be deemed compelling, constitutional infringement is impermissible. ${ }^{\text {it }}$ Second, even where that interest is found to be compelling, the Court must determine whether alternative means, less restrictive of constitutional rights, exist to effectuate that interest. ${ }^{\pi 5}$ Moreover, while these alternatives must "adequately" io safeguard the asserted state interest, it has never been held specifically that they must be equally protective of that interest. What must in fact be balanced is "the state's interest in the added effectiveness of the chosen means against the individual

73. See United States v. O'Brien, 391 U.S. 367, 376-77 (1969).

74. Shapiro v. Thompson, 394 U.S. 618, 634 (1969); Griswold v. Connecticut, 381 U.S. 479, 497 (1965) (Goldberg. J., concurring); Bates v. Little Rock, 361 U.S. 516, 524 (1960). But see California v. Byers, 402 U.S. 424, 463.64 (1971) (Black, J., dissenting), in which the very concept of balancing, of searching for cven a compclling state interest, is eschewed. In Justice Black's view, fundamental constitutional rights should simply not be subject to balancing.

75. See generally Wormuth \& Mirkin, The Doctrine of the Reasonable Altermative, 9 UTAH L. REv. 254 (1964); Note, Less Drastic Means and lihe First Amendment, 78 Yale L.J. 464 (1969).

76. Aptheker v. Secretary of State, 378 U.S. 500, 514 (1964); Dean Milk Co. v. Madison, 340 U.S. 949,354 (1951). 
interest in the use of less drastic ones." stitutional infirmities, the preclusion sanction can only be justified if the state interest served by that sanction is compelling and there exist no reasonably effective alternatives for promoting that interest which have a less drastic impact upon the rights of the accused.78

\section{State Interest}

The preclusion sanction is a means by which the state sceks to enforce prosecutorial pretrial discovery. However, such discovery is not sought by the state as an end in itself, but merely as a procedure for furthering two underlying state interests: preventing surprisc at trial $^{79}$ and reducing the trial load in overburdened courts. ${ }^{80}$ These interests are "compelling" with regard to the preclusion sanction only if two criteria are met: The interests must be important in and of themselves, and pretrial discovery must be the only method of adequately effectuating those interests. If either criterion is not satisfied, the state has not shown a compelling reason for precluding evidence which may be vital to the presentation of the defendant's case.

Although degrees of importance or "compellingness" are difficult to characterize and fit into neat categories, the basic interests served by prosecutorial pretrial discovery seem sufficiently important to demand judicial deference. First, the Court has endorsed the principle that the search for truth in the criminal process is enhanced if the prosecutor is informed of at least the basic outline of the defendant's case before the trial begins. ${ }^{81}$ This conclusion follows from the belief that the adversary process works best when each party is fully prepared to counter the arguments of the other. Second, the overcrowded dockets and serious delays which characterize the judicial system in many American jurisdictions today testify to the importance of the state interest in reducing the case load in its courts. ${ }^{82}$

77. Note, supra note 75, at 467-68.

78. In applying this balancing procedure, a court, though considering the alternatives suggested later in this Note (pp. 1356-60 infra) need not perform the legislative role of selecting a particular alternative to be implemented through the passage of new pretriat discovery statutes. All that a court must do is determine whether, given the available alternatives, there exists a procedure which will be sufficiently cffective to satisfy the asserted state interest. See Note, Blacklisting Through the Official Publication of Con. gressional Reports, 81 YaLE L.J. 188, 224.25 (1971).

79. Williams v. Florida, 399 U.S. 78, 81 (1970); State ex rel. Simos v. Burhe, 41 Wis.2d $129,133,163$ N.W.2d 177, 182 (1968); Waddington, Criminal Discovery and the Alibi Defense, 37 L.A.B. BulL. 7,8 (1953).

80. In this regard, it has been suggested that prosecutorial pretrial discovery will facilitate reduction of trial backlog by eliminating the need for trial completely in many cases. See Williams v. Florida, 399 U.S. 78, 105.06 (1970) (Burgcr, C.J., concurring).

81. Williams v. Florida, 399 U.S. 78, 81 (1970).

82. Burger, C.J., The State of the Judiciary-1970, 56 A.B.A.J. 929, 931 (1970). 
These interests, however, are only compelling with regard to the preclusion sanction if the pretrial discovery procedure which preclusion effectuates is actually necessary for the service of those interests. If alternative means of avoiding surprise and reducing court congestion are available, and those means do not entail the infringement of constitutional rights which results from application of the discovery/preclusion procedure, the state cannot show the requisite need for that procedure. ${ }^{83}$ Similarly, if pretrial discovery does not itself make a significant contribution to the realization of these two state interests, sufficient need for the discovery/preclusion procedure cannot be demonstrated.

The Court in Williams, having found no infringement of petitioner's Fifth Amendment rights through the use of the notice of alibi procedure, ${ }^{81}$ never reached this matter of alternatives to prosecutorial discovery. But a recent Note ${ }^{85}$ criticizing the Williams holding ${ }^{80}$ did discuss that question. In considering the state's interest in avoiding surprise at trial, the Note concluded that this goal could reasonably be achieved by a "more effective use of the state's enormous investigatory ability ...."si and by granting continuances in those cases in which the prosecutor is actually surprised. ${ }^{88}$ Because the state's interest in avoiding surprise may be satisfied by means other than prosecutorial discovery, the use of that procedure, although legitimate, lacks the urgency necessary to justify infringement of a defendant's constitutional rights. ${ }^{89}$

Similarly, while the state's general desire to reduce the trial load in its court system may be compelling under certain circumstances, there is no indication that pretrial discovery by the prosecution will significantly contribute to that reduction. The first argument in favor of pretrial discovery is that this procedure will lead to more frequent dismissals. This contention seems rather specious, however, considering that a defendant aware of persuasive exculpatory evidence will probably volunteer that information to the prosecutor..$^{90}$ Mandatory pretrial disclosure therefore is unlikely to do more than mini-

83. Since the preclusion sanction was not at issuc in Williams, 399 U.S. 78, 83 n.I4 (1970), and no other aspect of the Florida notice of alibi statute was found to infringe upon the petitioner's constitutional rights, this showing of necessity vas not required by the Court.

84. 399 U.S. at 86 .

85. Note, supra note 2.

86. Id. at 1006-08.

87. Id. at 1010 .

88. Id.

89. Id. at 1011 .

90. Williams v. Florida, 399 U.S. 78, 111 (1970) (Black, J., dissenting). 
mally increase the dismissal rate. On the other hand, requiring pretrial disclosure by the defendant may very well improve the efficiency of the plea bargaining procedure and, in that way, effectuate the state's interest in reducing the trial load. For example, by laying bare the weaknesses of potential defenses, pretrial disclosure will limit the defendant's ability to bluff, thereby increasing the pressure to plead guilty.

Yet, how significant is this greater informational flow to the institution of plea bargaining? First, the prosecutor already has superior investigative resources at his disposal through which to discover incriminating evidence. Second, and more importantly, the prosecutor has the flexibility to offer a wide range of deals to induce the defendant to plead guilty. While a defendant's increased ability to bluff in the absence of disclosure may bring about a lower sentence in the bargain, there is little probability that the defendant will risk trial and force that bluff to be called. Therefore, pretrial discovery would seem to add little to the effectiveness of plea bargaining in reducing the trial load. ${ }^{91}$

In summary, although the underlying state interests in avoiding surprise at trial and in reducing the trial load may be substantial, the use of pretrial discovery would appear unnecessary to achieving the former goal and of only marginal effectiveness in achieving the latter. Nevertheless, the term "compelling" is difficult to define, and a court might well find, contrary to the conclusion of this Note, that the state does have a compelling interest in utilizing the pretrial discovery procedure. However, even assuming arguendo that this might be established, the existence of methods of enforcing pretrial discovery less restrictive of individual rights than the preclusion sanction would make the use of that sanction unconstitutional.

\section{Alternative Sanctions}

Application of this "less drastic means" formula to the preclusion sanction requires an analysis of the effectiveness of the various alternatives, applied either individually or in concert in serving the state's interest in pretrial discovery, in view of the multitude of situations which might arise. In evaluating the net effectiveness of a particular sanction, recognition must be given to two factors: potential to

91. Of course, were plea bargaining itself to be found unconstitutional, as a recent Note has suggested (see Note, The Unconstitutionality of Plea Bargaining, 83 Hanv. L. REV. 1387, $1407(1970)$ ), then pretrial discovery, of benefit only in its support of plea bargaining, would be useless as a means of reducing the trial load. 
deter noncompliance with pretrial discovery statutes and cost of application to the state in terms of money and other resources. The degree of effectiveness of a proposed sanction will vary directly with the former and inversely with the latter. Furthermore, an appropriate method of measuring deterrent potential would be through the development of a cost-benefit analysis, ${ }^{92}$ from the point of view of the defendant. For example, where the perceived benefits of nondisclosure are low; even a rather light sanction may be sufficiently costly to deter violation.

The key to effective utilization of the range of sanctions open to the state is flexibility in applying them. The various sanctions differ in their severity, their focus and their effect on the trial process. In addition, the point in the process at which the defendant's failure to comply is ascertained may effect the utility of these alternatives. The following discussion will attempt to assimilate these considerations into an assessment of the probable effectiveness of the panoply of alternatives available to the state, as well as the impact of these alternatives on the rights of the accused.

a. Continuance. Although there have been suggestions that a continuance is really no sanction at all, ${ }^{33}$ it should still be used by the court as a remedial measure where, as permitted by many existing pretrial discovery statutes, the defendant can offer good cause for his failure to comply.94 As for deterrent value, a continuance has little direct cost to the defendant, ${ }^{95}$ but it should substantially reduce the primary benefit of intentional noncompliance-surprise. ${ }^{90}$ On the other hand, continuances are costly to the state in terms of administrative efficiency and are of limited feasibility in a jury trial.97

92. This term is used throughout this Note to depict a model for the thought process or reaction of a particular class of persons faced with a choice situation. It should not be confused with the more technical, empirically rigorous definition which the tcrm has received in economic planning literature.

93. Epstein, Advance Notice of Alibi, 55 J. Crim. L.C. \& P.S. 29, $35-36$ (1961).

94. In fact, only in Kansas must the court order preclusion with no exception for good cause shown. See KaN. STAT. AN. \$ 22-3218 (Supp. 1971); Epstcin, supra note 90, at 35 .

95. Nevertheless, to the innocent defendant who has either been denied bail or cannot afford it, the additional confinement period resulting from the continuance would be rather costly. As for those defendants who are in fact guilty, it has been argued that, far from being costly, delays can only work to their adiantage. While it is true that delay may lead to memory lapse or disappearance of witnesses, these crentualities are not likely to arise from the one limited continuance which may be granted to overcome surprise. This result can be contrasted with the more realistic possibility of such benefits flowing from long, repeated delays-such as may be required by continual courtroom disruptions or, perhaps, by the failure of the accused to appear at trial altogether.

96. Brief for Virgil Jenkins, Amicus Curiae at 23-24, Williams v. Florida, 399 US. 78 (1970); Note, supra note 2, at 1010. Note also that in Oklahoma the only sanction available to the court is a continuance. See note 14 supra.

97. Rezneck, New Federal Rules of Criminal Procedure, 54 GEo. L.J. 1276, 1293 (1960). 
b. Limiting Pretrial Discovery by the Defendant. A more drastic sanction than the continuance is the prohibiting of further discovery by the defendant. ${ }^{98}$ Given the minimal investigative resources often available to the defendant, this procedure may very well exert sufficient pressure to promote compliance. However, the court may be unaware of defendant's noncompliance until trial, thereby eliminating the applicability of this sanction completely. Furthermore, restriction of defense discovery would not only undermine the search for truth, which is thought to be enhanced by liberal discovery, ${ }^{00}$ but would also harbor constitutional defects like those of preclusion to the extent that the defendant has a constitutional right to pretrial discovery. ${ }^{100}$ Nevertheless, discovery foreclosure does not directly prevent the intro. duction of material evidence at trial and it must be viewed therefore as a sanction less drastic than outright preclusion.

c. Comment on Defendant's Failure to Comply. The opportunity for the prosecutor or the court to comment upon the credibility of evidence offered by the defendant, in view of his noncompliance, would seem to be a forceful deterrent to the defendant's wilful disobedience. ${ }^{101}$ While similar to the continuance in its negation of some of the benefits of surprise, comment adds a cost factor to the defendant lacking in the continuance remedy as a result of its influential impact upon the jury. Yet, despite this deterrent potential and the absence of application costs to the state, there is a possibility that this sanction is also constitutionally defective.

At the outset, since the defendant has no right of noncompliance, comment would not represent an impermissible burden on the exercise of a constitutional right. ${ }^{102} \mathrm{~A}$ more difficult question, however, is raised by the due process ramifications of comment. In order to satisfy the requirements of due process, a comment on the credibility of evidence must be based on the existence of some rational connection between a characteristic of the evidence and the likely truth or falsity of that evidence. ${ }^{103}$ Whereas the rational connection between

98. This sanction was recommended in Note, Criminal Law: Constitutionality of Conditional Mutual Discovery Under Federal Rule 16, 19 OK1. L. REv, 419, 424 (1966). 99. See note 79 supra.

100. Rezneck, supra note 94, at 1289-90. Cf. Brady v. Maryland, 373 U.S. 83 (1969).

101. The detrimental impact of comment on the defendant was recognized by thic Court in Griffin v. California, 380 U.S. 609, 614 (1965). In that case, comment on the defendant's assertion of his Fifth Amendment privilege against self-incrimination wats held to be sufficiently costly to the defendant so as to represent an impermissible burclen on the exercise of a constitutional right.

102. See also Griffin v. California, 380 U.S. 609 (1965).

103. Cf. Quercia v. United States, 289 U.S. 466 (1933). 
intentional nondisclosure and evidentiary untrustworthiness lacks the degree of certainty necessary to justify the irrebuttable presumption supporting preclusion, ${ }^{104}$ it probably has sufficient inferential value to permit a comment on credibility. ${ }^{105}$ Consequently, this sanction will not be effective at the expense of defendant's constitutional rights.

d. Criminal Sanctions for Failure to Comply. The fourth alternative available to the state is the promulgation of a statute which would make the wilful refusal to comply with a pretrial discovery order a criminal act. Such a statute would be similar to those already enacted to penalize the defendant's wilful failure to appear at trial. ${ }^{100}$ Furthermore, although this sanction is parallel in effect to a contempt citation, it affords the defendant all of the procedural safeguards absent in that abbreviated proceeding. ${ }^{107}$ Nevertheless, there are two factors which may reduce the net effectiveness of this sanction. First, for those defendants facing long prison terms, the incremental burden of a small additional sentence will not be a great deterrent. Second, limitations on judicial resources make the necessity of another trial burdensome to the state.

e. Contempt Against Counsel. Whereas the foregoing alternatives rely for deterrence on penalizing the defendant to gain compliance, this last sanction focuses on counsel. ${ }^{108}$ In contrast to the fourth alternative, the effectiveness of imposing a short prison term on counsel will not be diluted through comparison with the possibility of incurring a more severe sentence. Moreover, while the defendant benefits directly from noncompliance, counsel does so only in his representative capacity. In short, applying a cost-benefit analysis from counsel's point of view would lead to the conclusion that this sanction possesses great deterrent potential. ${ }^{103}$

On the other hand, the applicability of this alternative depends on

104. See pp. 1349-5I supra.

105. Comment has been recognized as valid under similar inferences of unreliability; although preclusion had been found impermissible. See United States v. Nolte, 440 F.2d 1124. 1126 (5th Cir. 1971); Braswell v. Wainwright, 330 F. Supp. 281, 281, note 3 (S.D. Fla. 1971).

106. See, e.g., Conn. Gev. Stat. Rev. \$ $53-154$ (1908).

107. For criticism of the contempt sanction see The Supreme Court, 1969 Term, 84 HARv. L. REv. 31, 99-100 (1970). Despite its drawbacks, however, the availability of the contempt sanction should not be overlooked in the event that the legislature fails to provide the other alternatives discussed in the text.

108. It is doubtful that counsel, consistent with his representative function, would in fact be free to comply with a pretrial discovery order over the objection of the defendant. Probably the most that counsel can do, if his client refuses disclosure, is to withdraw from the case.

109. Rezneck, supra note 94 , at 1294. 
counsel's awareness of the existence of evidence for which the prosecutor has requested discovery. As a result, a defendant might seek to frustrate the use of this sanction by withholding information from counsel. Such a communications breakdown may well undermine the effective assistance of counsel. Thus, this sanction might abridge constitutional rights effectively by denying the defendant his right to counsel, ${ }^{110}$ as well as undermining an essential prerequisite of the adversary system: that each advocate have as much knowledge as possible about the facts of his client's case. ${ }^{111}$ However, the seriousness of this problem should be diminished by the defendant's interest in full communication, in permitting counsel to develop a more complete case.

\section{Preclusion in the Balance}

Following this examination of the alternatives available to the state, the balancing test embodied in the less drastic means analysis may now be employed. The relevant question becomes: does the state's interest in the added effectiveness of the preclusion sanction as a means of enforcing pretrial discovery outweigh the limitation placed by that sanction upon the defendant's Sixth Amendment right to present a defense? ${ }^{112}$

First, in order to determine the probable effectiveness of the alternatives suggested above there must be an assessment of both their deterrent potential and their cost of application when used in whatever combination will best serve the interests of the state. As to deterrent potential, contempt against counsel should prove effective in those cases in which counsel is aware of the relevant information. Moreover, the number of cases of defendant's nondisclosure to counsel should be minimal. This conclusion is supported by a rough costbenefit analysis: the costs to the defendant from his secrecy (an additional criminal penalty and the handicapping of his counsel) being in most cases greater than the benefits that can be derived from his failure to disclose (since the combination of continuance and comment substantially reduces the advantage of surprise). Implementa-

110. Note, supra note 2, at 1003 n.35.

111. Freedman, Professional Responsibility of the Criminal Defense Lau'ycr: The Three Hardest Questions, 64 MICH. L. REv. 1469, 1469.74 (1966).

112. It is important to bear in mind, in assessing this balance, that it is not the state's interest versus the interest of the individual defendant which is at stakc. On thc contrary, it is the interest of all defendants in asserting their right to present a defense which must be offset against the state's interest. See Reich, The New Property, 73 Yats L.J. 733, 776.77 (1964). 
tion of these alternatives would entail certain costs of application, primarily because of the increased resources required by continunances and additional trials. These costs, however, would not seem to justify the infringement of Sixth Amendment rights which results from the use of the preclusion sanction.

While several of the alternatives suggested above involve the possibility of various constitutional objections, none entails the danger raised by the preclusion sanction that the outcome of a trial might be changed. The preclusion sanction alone threatens to permit the conviction of an individual who is innocent of the crime for which he is charged because of his commission of a separate wrong-the failure to comply with pretrial discovery. To risk conviction on such erroneous grounds seems directly to conflict with "a fundamental value determination of our society that it is far worse to convict an innocent man than to let a guilty man go free."113

Finally, when balancing a loss of effectiveness in the administration of the criminal process against the cost of convicting an innocent defendant, consideration should be given to the suggestion that the Constitution itself, by commanding that the defendant be permitted to present his defense, may reflect a deliberate resolution of this balance. ${ }^{114}$ With this in mind, and in view of the questionable urgency of the state's interest in pretrial discovery, ${ }^{115}$ the advantage to the state afforded by preclusion must be more than marginal to justify such constitutional infringement under the compelling state interest test. $^{116}$

113. In re Winship, 397 U.S. 358,372 (1970) (Harlan, J., concurring).

114. Cf. Williams v. Florida, 399 U.S. $78,113-14$ (1970) (Black, J., discenting). Sec also Note, supra note 2, at 1009 n.60, in which the author's discussion of this possibility with regard to the Fifth Amendment is applicable to the Sixth Amendment right to present a defense as well.

115. See pp. $1355-56$ supra.

116. A comparison with two analogous instances in which courts have faced the incompatibility of the state's interest, on the onc hand, and a defendant's constitutional rights, on the other, may prove helpful at this point. The first area is the domain of government privilege, in which the state's interest in secrecy, in order to protect cither state secrets or informants, may conflict with the defendant's right to present a defense. Where the government has sought to invoke either of these privileges, most courts have held that the government must choose between dismissal of the charges or loss of the privilege. See Roviaro v. United States, 353 U.S. 53, 60.62 (1957) (intormant privilege), and United States v. Coplon, 185 F.2d 629, 638 (2d Cir. 1950); United States v. Andolschel, 142 F.2d 503, 506 (2d Cir. 1944) (state secret privilegc). Although no meaningful com. parison can be drawn between the degree of urgency of the state's interest in secrec) versus its interest in pretrial discovery, it should be noted that dismissal is a far more costly alternative to the state than the alternatives to preclusion suggested at pp. 1350 . 60 supra.

A second area of conflict between interests of the state and the rights of the defendant arises when a defendant persists in disrupting the trial procecdings. To eject the defendant from the courtroom would infringe his right to confront the witnesses against him, as guaranteed by the Sixth Amendment, but to permit him to remain might impair the state's interest in a trial free of disorderly interruption and spectacle. 


\section{B. Conditional Privilege Test}

A second theory by which courts have justified the preclusion sanction derives from a conditional privilege argument. Under this theory, where the discovery statute provides for the conditioning of defense disclosure on prior disclosure by the prosecution, ${ }^{117}$

the restrictions imposed ... do not come into operation until and unless the defense activates them. Thus, assuming arguendo that the exclusion infringes on an absolute right, the infringement, if any, is brought about solely by the action of the defense. ${ }^{118}$

In Illinois v. Allen, 397 U.S. 337 (1970), the Court chose to resolve this conflict in favar of the state's interest where the defendant "insists on conducting himself in a matuner so disorderly, disruptive, and disrespectful of the court that his trial cannot be carried on with him in the courtroom." Id. at 343. Although this decision seems to be based an the theory that the defendant's actions amounted to a "waiver through misconduct" of the right to remain in the courtroom and confront witnesses, this position has becn effectively criticized in Tigar, Waiver of Constitutional Rights: Disquiet in the Citadcl, Forward to The Supreme Court, 1969 Term, 84 Harv. L. REv. 1, 7.8 (1970). In fact, the Allen Court probably should have employed a balancing test, similar to the one described in the text. See The Supreme Court, 1969 Term, supra note 107, at 96.

Although it is again difficult to compare state interests, a comparison of the respectlve alternatives reveals that those designed to enforce pretrial discovery are inore likely to be effective than those thus far developed to prevent uncontrollable outbursts at irial. The Court in Allen mentions two possible alternatives to removing the defendant from the courtroom: physical restraint and summary contempt. See Helwig, Coping wilh "llc Unruly Criminal Defendant: The Options of the Allen Case, 7 Gonzaci L. REv. 17, 17.18 (1971). As to the former, its costs of application are so great as to render it a virtually useless alternative. 397 U.S. at 350 (1970) (Brennan, J., concurring). As for summary contempt, this sanction might be applied in two different ways. First, a court might use a civil contempt procedure in which the defendant would be imprisoned until lic agreed to refrain from further outbursts. The Court, however, noted a basic defect in this alternative in that the defendant may seek to profit from the resulting unavailability of adverse witnesses due to this prolonged, self-defined delay. $I d$. at 345 . $\mathrm{As}$ for criminal contempt, in which the defendant is sentenced to a prison term after the trial is coll. cluded, resort to a cost-benefit analysis from the defendant's standpoint indicates thit the cost of additional confinement will not be nearly so great a deterrent in the Allen situation as it should be in enforcing pretrial discovery. Specifically, the benefits of permanent disruption, alluded to above, will be greater than those of surprise, es. pecially where the benefits of the latter are reduced by continuance and comment. In addition, irrespective of these strategical differences, whereas courtroom disruptions may have propaganda value in a political trial, it is doubtful that a similar benefit would attach to the failure to comply with pretrial discovery. Therefore, although the bencfits of permanent disruption will more likely outweigh the cost of additional confincment, this should not be so in the pretrial discovery situation.

Finally, the infringement of constitutional rights inherent in removal docs not appear to be as significant as that resulting from the preclusion of matcrial evidence. Becattsc a defendant can both view the trial and communicate with his attorncy after he is removed from the courtroom, the deleterious effect of removal on the scarch for truth should be less than that wrought by preclusion. In sum, while the state interests in this comparison might arguably be equal, the alternatives available to enforce pretrial discovery are more effective, and the cost of preclusion, in terms of harm to the de* fendant, is greater than for the removal sanction. Consequently, although loss of the right of confrontation may be practically unavoidable in controlling courtroom distup. tions, the same degree of necessity does not arise to justify the use of preclusion to ent. force pretrial discovery.

117. See, e.g., FlA. R. Crim. P. \$ 1.220(c), (c) (1967); Proposed Rule 16, at 591.95.

118. Cacciatore v. State, 226 So.2d 137, 140 (Fla. App. 1969). 
Thus, an attempt is made to justify preclusion on the grounds that the defendant has chosen to waive his Sixth Amendment right to present a defense as a condition of accepting the benefit of pretrial discovery. The theory, however, clearly violates the doctrine of unconstitutional conditions. ${ }^{119}$ Pursuant to this theory, the conditional waiver of a constitutional right is impermissible where such condition bears no reasonable relationship to the benefit offered.120 The state may contend that such a relationship between benefit and condition exists, and that affording the defendant pretrial discovery requires similar discovery by the prosecution. This assertion has been questioned. ${ }^{121}$ Even were it valid, however, it would only justify the conditional waiver ${ }^{122}$ of the right to present a defense if that were the only means by which the state could be assured of reciprocal discovery. ${ }^{123}$ In short, the less drastic means analysis employed in the preceding section is equally applicable here. ${ }^{124}$ If it is found that the alternative sanctions heretofore examined are sufficiently likely to protect the state's interest in pretrial discovery, the fact that discovery is reciprocal will not save the preclusion sanction from being unconstitutional.

119. See Amendments to Rules of Civil Procedure, Supplemental Rules for Certain Admiralty and Maritime Claims, Rules of Criminal Procedure, 39 F.R.D. 69, 276.78 (1960) (Douglas, J., dissenting from Rule 16), in which Justice Douglas argues that rcciprocal discovery might unconstitutionally condition the loss of the defendant's Fifth incnd. ment privilege against self-incrimination. While this view was answered by the Court's holding in Williams that there was no loss of the privilege in the first place, Douglas' reasoning remains applicable to the conditional waiver of the defendant's Sixth Amend. ment right to present a defense, as discussed in the text, pp. 1362.63 supra. For a good discussion of the doctrine of unconstitutional conditions see Notc, Another Lool at Unconstitutional Conditions, 117 U. PA. L. REv. 144 (1968).

120. Note, Unconstitutional Conditions, 73 HARv. L. Rev. 1595, 1596 (1960).

121. Note, supra note 2, at 1011 n.64.

122. Although in this instance waiver is part of a conditional benefit pattem, the waiver concept might also be employed where discovery is not reciprocal. In stich a case, waiver might be couched in the following terms: as long as the defendant is aware that his failure to supply information demanded by the prosecution will Iead to the possible loss of his right to present a defense, his choice not 10 comply amounts to a knowing waiver of that right. The difficulty with this approach is that it misconstrues the purpose of the waiver option. Defendants are permitted to vaive constitutional rights where those rights and certain perceived benefits are inherently mutually exclusive. For example, it is obvious that an accused cannot simultancously represent himsclf and have the right to counsel. On the other hand, in the case of preclusion, the perceived benefit of nondisclosure and the right to present a defense are not naturally antithetical. Without this state-imposed sanction, the defendant who chose not to diselose could still present his defense at trial. Consequently, the waiver in this case is the product of a choice situation manufactured by the state to effectuate the state interest in pretrial disclosure. As such, the relevant inquiry is the same as umder the compelling state interest test, again involving the application of the doctrine of the reasonable alternative.

123. Note, supra note 119 , at 156-57.

124. Id. 


\section{Conclusion}

In Washington v. Texas, ${ }^{125}$ the Supreme Court established that the Compulsory Process Clause of the Sixth Amendment afforded the defendant a right to present all relevant and material testimony in his defense. In so holding, the Court was simply recognizing a policy, long advocated by courts ${ }^{126}$ and commentators ${ }^{127}$ alike, that elimination of the antiquated doctrine of presumptive untrustworthiness would strengthen the adversary process. Yet, the sanction of preclusion, based on this discredited doctrine, has been embodied in numerous state and federal pretrial discovery statutes. The result is evident: an infringement of the defendant's constitutional rights.

On balance, the justifications for this infringement are unpersuasive. The prosecutorial pretrial discovery procedure may arguably be the only means of promoting certain compelling state interests, and constitutional infringement might be permissible if preclusion were the only effective sanction for enforcing this discovery procedure. But other procedures less drastic than prosecutorial pretrial discovery may be used to achieve the asserted state interests. Furthermore, even if pretrial disclosure by the defendant is necessary, a range of alternative sanctions is available which, if implemented properly, should adequately enforce disclosure while restricting the rights of the accused less drastically. The right to present a defense is a fundamental element of due process. ${ }^{128}$ In the absence of necessity, that right may not be overborne by legislative fiat or judicial discretion.

125. 388 U.S. 14 (1967).

126. See note 46 supra.

127. See note 53 supra.

128. Washington v. Texas, 388 U.S. 14, 19 (1967). 